Improved work practices may decrease injuries by limiting uncontrolled movements of instruments under force (eg, scalers or laboratory knives) or by restricting the use of fingers to retract tissue during suturing or administration of anesthesia. Bur injuries may be avoided by removal of the bur before placing the handpiece in the dental unit. Because injuries often involve the fingers and hands, the continued development of personal protective equipment such as puncture-resistant gloves and thimbles may be important. Once developed, however, these preventive interventions must be evaluated to determine whether they reduce blood exposures among dental workers without adversely affecting patient care.

\section{REFERENCES}

1. Klein RS, Phelan JA, Freeman K, et al. Low occupational risk of human immunodeficiency virus infection among dental professionals. N Engl J Med 1988;318:86-90.

2. Siew C, Chang S, Gruninger S, Verrusio C, Neidle E. Selfreported percutaneous injuries in dentists: implications for HBV, HIV transmission risk. JADA 1992;123:37-44.

3. Gonzalez CD, Pruhs RJ, Sampson E. Clinical occupational bloodborne exposure in a dental school. J Dent Educ 1994;58:217-220.

4. Cottone JA, Dillard RL, Dove SB. Frequency of percutaneous injuries in dental care provider. J Dent Educ 1992;56:96. Abstract 14

5. Wisnom C, DePaola L, Overhoster CD, Lee R. A five-year study of parenteral exposures in dental health care workers. Fifth National Forum on AIDS, Hepatitis, and Other Bloodborne Diseases; Atlanta, GA; 1993. Abstract P163.

6. Siew C, Gruninger SE, Miaw C, Neidle EA. Percutaneous injuries in practicing dentists. JADA 1995;126:1227-1234.

7. Cleveland JL, Lockwood SA, Gooch BF, Chamberland ME, the
Dental Cooperative Study Group. Percutaneous injuries during dental procedures: an observational study. JADA 1995;126:745751 .

8. Malvitz DM, Siew C, Cleveland JL, Gruninger SE. Hepatitis B exposure and vaccination among dental hygienists and dental assistants. Journal of American Dental Hygiene 1995;69:275. Abstract.

9. Gooch BF, Siew C, Cleveland JL, Gruninger S, Lockwood SA. Occupational exposures reported by oral surgeons-United States, 1992. J Dent Res 1995;74:22. Abstract 85.

10. Carlton JE, Dodson TB, Cleveland JL, Lockwood SA. Percutaneous injuries during oral and maxillofacial surgery. $J$ Oral Maxillofac Surg. 1997;55:553-556.

11. Gooch BF, Cardo DM, Marcus R, et al. Percutaneous exposures to HIV-infected blood among dental workers enrolled in the CDC needlestick study. JADA 1995;126:1237-1242.

12. Tokars JI, Bell DM, Culver DH, et al. Percutaneous injuries during surgical procedures. JAMA 1992;267:2899-2904.

13. Panlilio AL, Foy DR, Edwards JR, et al. Blood contacts during surgical procedures. JAMA 1991;265:1533-1537.

14. Gerberding JL, Littell C, Tarkington A, Brown A, Schecter WP. Risk of exposure of surgical personnel to patients' blood during surgery at San Francisco General Hospital. $N$ Engl J Med 1990;322:1788-1793.

15. Nash KD. How infection control procedures are affecting dental practice today. J Am Dent Assoc 1992;123:67.

16. Beekmann SE, Henderson DK. Managing occupational risks in the dental office: HIV and the dental professional. JADA 1994;125:847-852.

17. Hazelcorn HM, Bloom BE, Jovanovic BD. Infection control in the dental office: has anything changed? JADA 1996;127:786790 .

18. Centers for Disease Control. Update: Universal Precautions for prevention of transmission of human immunodeficiency virus, hepatitis B virus, and other bloodborne pathogens in healthcare settings. MMWR 1988;37:377.

19. Centers for Disease Control and Prevention. Recommended infection-control practices for dentistry, 1993. MMWR 1993; 41(RR-8).

20. Moseley JW, Edwards VM, Casey G, Redeker AG, White E. Hepatitis B virus infection in dentists. N Engl J Med 1975; 293:729.

\title{
HICPAC Draft Guideline for Infection Control in Health Care Personnel, 1997
}

The HICPAC "Draft Guideline for Infection Control in Health Care Personnel, 1997" will be published for review and comment in the Federal Register as Part V on September 8, 1997. Below is a portion of the Federal Register notice.

The deadline for written comments is October 17, 1997. The Federal Register is now available on the Internet (address below), and there is a link to the document on the Hospital Infections Program, National Center for Infectious Diseases, and Centers for Disease Control and Prevention (CDC) home pages under "What's New."

Written comments on the draft document must be received on or before October 17, 1997.

Comments on this document should be submitted in writing to the
CDC, Attn: PHG Information Center, Mailstop E-68, 1600 Clifton Rd NE, Atlanta, GA 30333.

To order copies of the Federal Register containing the document, contact the US Government Printing Office, Order and Information Desk, Washington, DC 20402-9329, telephone (202) 512-1800.

In addition, the Federal Register containing this draft document may be viewed and photocopied at most libraries designated as US Government Depository Libraries and at many other public and academic libraries that receive the Federal Register throughout the country. Addresses and telephone numbers of the US Government Depository Libraries are available by fax by calling US Fax Watch at (202)512-1716 and selecting option 5 from the main menu.
The draft document can be found on the Web at http://frwebgate2. access.gpo.gov/cgi-bin/waisgate. cgi? WAISdocID=0099130659+14+0+0\& WAISaction=retrieve. (Note: type as one continuous line of text, no spaces or returns.)

The Federal Register also is available online at the Superintendent of Documents home page, http://www. access.gpo.gov/su_docs.

For further information, contact the CDC Fax Information Center, telephone (888)232-3299, and order document \#370112, or telephone 404-6396425 and press $2,2,3,2,2,1,5$ to go directly to the information.

To order a copy of the guideline by telephone, please call 1-888-2323228 . Please specify you want document \#370160. 